\title{
Challenges in Integrating New Teacher Development Program in Schools: A Systematic Literature Review
}

\author{
Zuliani Kamaruddin*, Yusof Boon \\ School of Education, Faculty of Social Science \& Humanities, University Technology of Malaysia, Malaysia
}

Received January 22, 2020; Revised April 1, 2020; Accepted April 21, 2020

Copyright $\odot 2020$ by authors, all rights reserved. Authors agree that this article remains permanently open access under the terms of the Creative Commons Attribution License 4.0 International License

\begin{abstract}
Education transformation will be more effective if a particular focus is placed on efforts to improve student achievement and at the same time emphasis is placed on initiatives to continually build teacher capacity throughout their careers. In line with this, the National Key Result Areas (NKRA) Teacher Quality ruled that the New Teacher Development Program (NTDP) was one of fifteen initiatives to be implemented to ensure excellence in the teaching profession. The New Teacher Development Program (NTDP) is a school based structured learning program to support the development of new teacher professionalism to improve teacher quality in the teaching profession. The NTDP is also a socialization process for the teaching profession that helps new teachers to make adjustment between existing knowledge and skills with procedures, school systems and effective teaching skills and classroom management skills. However, there are many obstacles and challenges in integrating New Teacher Development Program in school. This study provides an overview of the challenges faced by the schools in integrating the program for new teacher's professional development. Selected research papers, published from 2012 to 2019, were downloaded from Springer Link, Science Direct, Google Scholar, Taylor \& Francis Online, SAGE, JSTOR, Web of Science and Emerald. Findings from this review showed that the new teacher commitment is the main challenge to initiate, develop and integrate New Teacher Development Program in schools. It is also beneficial to school administrators and educators to cater and understand the teacher attitude and readiness, both before and during the implementation phase of the program.
\end{abstract}

Keywords Challenges, New Teacher, New Teacher Development Program, New Teacher's Professional Development

\section{Introduction}

The New Teacher Development Program (NTDP) is a school based structured learning program to support the development of new teacher professionalism to improve teacher quality in the teaching profession. It is also a socialization process for the teaching profession that helps new teachers to make adjustment between existing knowledge and skills they have learned before with school systems, procedures and effective teaching skills and classroom management skills [1].

The New Teacher Development Program (NTDP) is one of the programs that supports the development of new teacher's continuing professionalism, which is the first-time teachers enter the education service and are housed in schools. This program is implemented on a school-based basis through structured guidance and includes Orientation Phase, Teaching Phase and Professional Development Phase. The duration of implementation of this program is between one to three years. An experienced mentor teacher will guide the new teachers to learn about the school environment and culture and gain a deeper understanding of the system and aspirations of national education.

The NTDP can have a positive impact on schools, teachers and pupils while fostering an excellent work culture for new teachers to be able to perform tasks and responsibilities more systematically. Guided by mentor teachers through the mentoring system, experienced teachers and school administrators, it is hoped that new teachers will be able to implement teaching and learning more effectively and professionally so that this practice will improve the teaching profession in the country. This program has already been implemented in the teaching profession in developed countries to improve teacher quality. In addition, dynamic and global education requires teachers who are ready to continuously improve the quality of education [2].

There are still many issues faced by new teachers in schools although there have been strong efforts by the ministry to address issues and problems of new teachers [3]. 
The challenges and issues involving new teachers are not limited to classroom issues only as they face other challenges as they begin to become teachers, especially on issues related to their attitude, competency, motivation, stress and emotion and their commitment to the organization.

The question is, how far are new teachers responding to and implementing change in the school and classroom? Is the change just passing through in the form of documentation and not on teacher implementation and practice? This is because, if the teachers that are the main drivers and players of this change and transformation but do not play an effective role with proactive involvement and commitment, efforts and actions of the Ministry of Education Malaysia in realizing the philosophy of national education will interrupted [4]. The school administrators must put an effort to guide and give motivation and guidance to new teachers in implementing New Teacher Development Program in order to perform well and successfully.

\section{Research Question}

The objective of this study is to gain an overview of the main challenges faced by school administrators or educators in integrating and implementing New Teacher Development Program in schools. This study also reviewed the dimensions or features towards the program. This study is also aimed to answer the research questions stated below:

- What are the main challenges faced by school administrators or educators to integrate and implement New Teacher Development Program in schools?

- What are the main dimensions or features associated with New Teacher Development Program?

\section{Methodology}

In this study, the systematic literature review was employed. Selected research papers from 2012 to 2018 were downloaded from Springer Link, Science Direct, Google Scholar, Taylor \& Francis Online, SAGE, JSTOR and Web of Science and Emerald. Most of these articles are basically from the social science journals, for instance the Journal of Educational Research, Journal of Teacher Education, Journal of Education and Practice and Educational Leadership Journal.

Using these prominent databases, it provides good research platforms where multi-disciplinary issues can be found. In light of this, for this study, integrating and implementing New Teacher Development Program in schools and the challenges faced by the school administrators and educators were used as references in the database searching platform. Based on the searching result, most of the research papers in the databases showed the dimension relating to the issues of challenges in integrating New Teacher Development Program in schools.

During the initial stage, the search found a total of 98 papers which were related to teacher's development program in schools. During the second stage, the number of articles found were reduced to a total of 29 which fulfilled these criteria: (1) The selected papers were limited to only those published from 2012 to 2018 in order to obtain the latest reviews regarding the integration and implementation of New Teacher Development Program in schools, (2) The studies were related to challenges in integrating and implementing New Teacher Development Program faced by school administrators and educators. The studies also were analyzed and summarized according to the research questions, as presented in Table 1 and Table 2. 


\subsection{Tables}

Table 1. Analysis on the challenges faced by school administrators and educators in integrate and implement New Teacher Development Program in schools.

\begin{tabular}{|c|c|c|c|c|c|c|c|c|c|c|c|c|}
\hline $\begin{array}{l}\text { Author (s), } \\
\text { Year }\end{array}$ & Attitude & Self-efficacy & Motivation & $\begin{array}{c}\text { Commit } \\
\text { ment }\end{array}$ & $\begin{array}{c}\text { Teacher } \\
\text { Professionalisms }\end{array}$ & \begin{tabular}{|c|} 
Emotiona \\
1 stress
\end{tabular} & Perception \& Perspective & Competency & Readiness & $\begin{array}{c}\text { Class } \\
\text { management }\end{array}$ & \begin{tabular}{|c|} 
Commun \\
ication
\end{tabular} & $\begin{array}{l}\text { Support } \\
\text { structure }\end{array}$ \\
\hline Radziah 2013 & & & & & & & & & & & & \\
\hline $\begin{array}{l}\text { Moriza } \\
2017\end{array}$ & & & & & & & & & & & & \\
\hline $\begin{array}{l}\text { Aziah } \\
2015\end{array}$ & & & & & & & & & & & & \\
\hline $\begin{array}{c}\text { Mavroulis } \\
2013 \\
\end{array}$ & & & & & & & & & & & & \\
\hline $\begin{array}{c}\text { Poom-Valickis } \\
2014 \\
\end{array}$ & & & & & & & & & & & & \\
\hline $\begin{array}{l}\text { Senom, Razak Zakaria, } \\
\text { \& Sharatol } 2013\end{array}$ & & & & & & & & & & & & \\
\hline $\begin{array}{c}\text { Zakaria } \\
2015\end{array}$ & & & & & & & & & & & & \\
\hline $\begin{array}{c}\text { Noor Shamshinar, Zetty Nurzuliana } \\
\text { \& Mohd Kama, } 2014\end{array}$ & & & & & & & & & & & & \\
\hline $\begin{array}{c}\text { Ghavifekr, Lim, Hoon, Ling, \& } \\
\text { Ching } \\
2014\end{array}$ & & & & & & & & & & & & \\
\hline $\begin{array}{c}\text { Sofiah, Khaliza \& Rozi } \\
2017\end{array}$ & & & & & & & & & & & & \\
\hline $\begin{array}{c}\text { Akcan } \\
2016\end{array}$ & & & & & & & & & & & & \\
\hline $\begin{array}{l}\text { Blomberg \& Knight } \\
2015\end{array}$ & & & & & & & & & & & & \\
\hline Hao Xu 2012 & & & & & & & & & & & & \\
\hline $\begin{array}{l}\text { Horn \& Campbell } \\
\qquad 2015\end{array}$ & & & & & & & & & & & & \\
\hline Hasan Tanang 2014 & & & & & & & & & & & & \\
\hline $\begin{array}{c}\text { Gaikhorst, Beishuizen, Korstjens, } \\
\text { \& Volman } 2014\end{array}$ & & & & & & & & & & & & \\
\hline $\begin{array}{l}\text { Noredayu, Mahaliza, Hamidah } \\
2016\end{array}$ & & & & & & & & & & & & \\
\hline $\begin{array}{l}\text { Saedah \& Mohammed Sani } \\
2012 \\
\end{array}$ & & & & & & & & & & & & \\
\hline $\begin{array}{l}\text { Nik Noraini \& Noor Hisham } \\
2018\end{array}$ & & & & & & & & & & & & \\
\hline $\begin{array}{c}\text { Gregory W. Stevens } \\
2013\end{array}$ & & & & & & & & & & & & \\
\hline
\end{tabular}




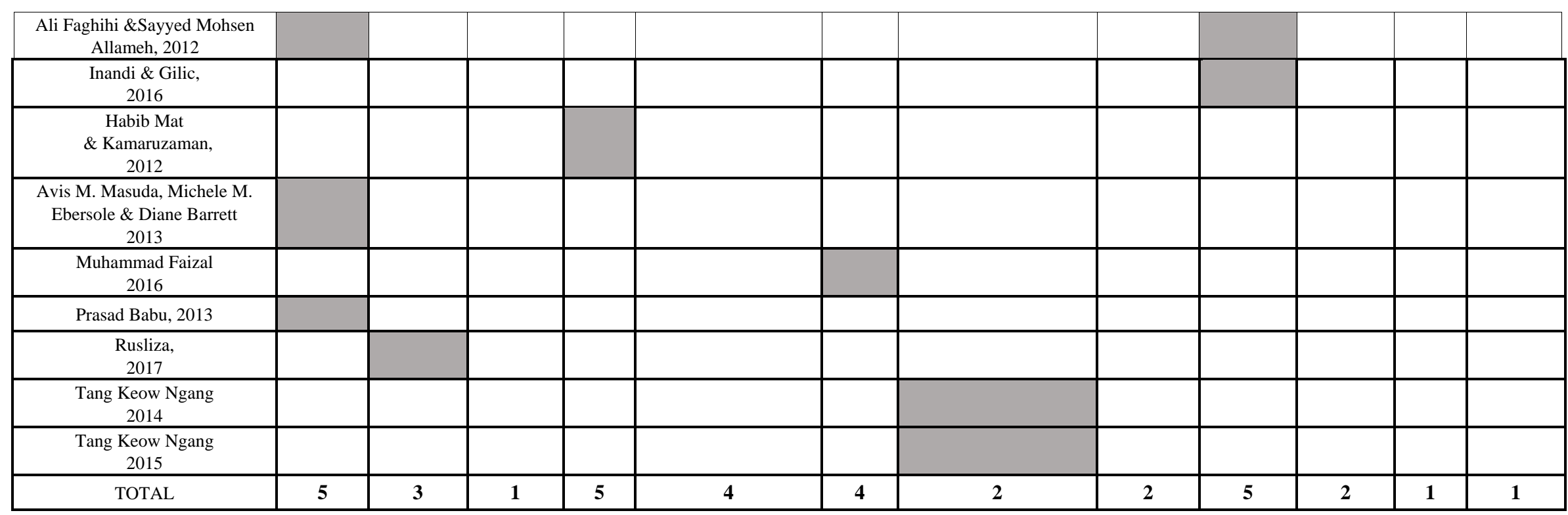

Table 2. Analysis on the dimensions or features associated with New Teacher Development Program in previous studies

\begin{tabular}{|c|c|c|c|c|c|c|c|c|c|c|c|c|c|}
\hline $\begin{array}{l}\text { Author (s), } \\
\text { Year }\end{array}$ & $\begin{array}{c}\text { Enhance } \\
\text { achievement }\end{array}$ & Responsibility & $\begin{array}{c}\text { Classroom } \\
\text { management }\end{array}$ & $\begin{array}{c}\text { Emotional } \\
\text { relationship \& } \\
\text { management }\end{array}$ & $\begin{array}{l}\text { Problem- } \\
\text { solving skills }\end{array}$ & $\begin{array}{c}\text { Support \& } \\
\text { guidance }\end{array}$ & $\begin{array}{c}\text { Self } \\
\text { confidence }\end{array}$ & $\begin{array}{c}\text { Transparence } \\
\text { Communication }\end{array}$ & $\begin{array}{l}\text { Skills and } \\
\text { knowledge }\end{array}$ & $\begin{array}{c}\text { Commitment } \\
\text { and intention } \\
\text { to change }\end{array}$ & $\begin{array}{l}\text { Transformation } \\
\& \text { intervention }\end{array}$ & $\begin{array}{c}\text { Collective } \\
\text { work \& } \\
\text { teamwork }\end{array}$ & \begin{tabular}{|c|} 
Ethics \& \\
personal \\
development \\
\end{tabular} \\
\hline Radziah 2013 & $\checkmark$ & & & & & & & & & & & & \\
\hline $\begin{array}{l}\text { Moriza } \\
2017\end{array}$ & & $\checkmark$ & & & & & & & & & & & \\
\hline \begin{tabular}{|c|} 
Aziah Ismail \\
2015 \\
\end{tabular} & & & $\checkmark$ & & & & & & & & & & \\
\hline Mavroulis2013 & & & & $\checkmark$ & & & & & & & & & \\
\hline \begin{tabular}{|c} 
Poom-Valickis \\
2014 \\
\end{tabular} & & & & & $\checkmark$ & & & & & & & & \\
\hline \begin{tabular}{|l} 
Senom, Razak \\
Zakaria, \& \\
Sharatol 2013 \\
\end{tabular} & & & & & & $\checkmark$ & & & & & & & \\
\hline \begin{tabular}{|c} 
Zakaria Mohd \\
Arif \\
2015 \\
\end{tabular} & & & & $\checkmark$ & & & & & & & & & \\
\hline $\begin{array}{c}\text { Noor } \\
\text { Shamshinar, }\end{array}$ & & & & & & & $\checkmark$ & & & & & & \\
\hline
\end{tabular}




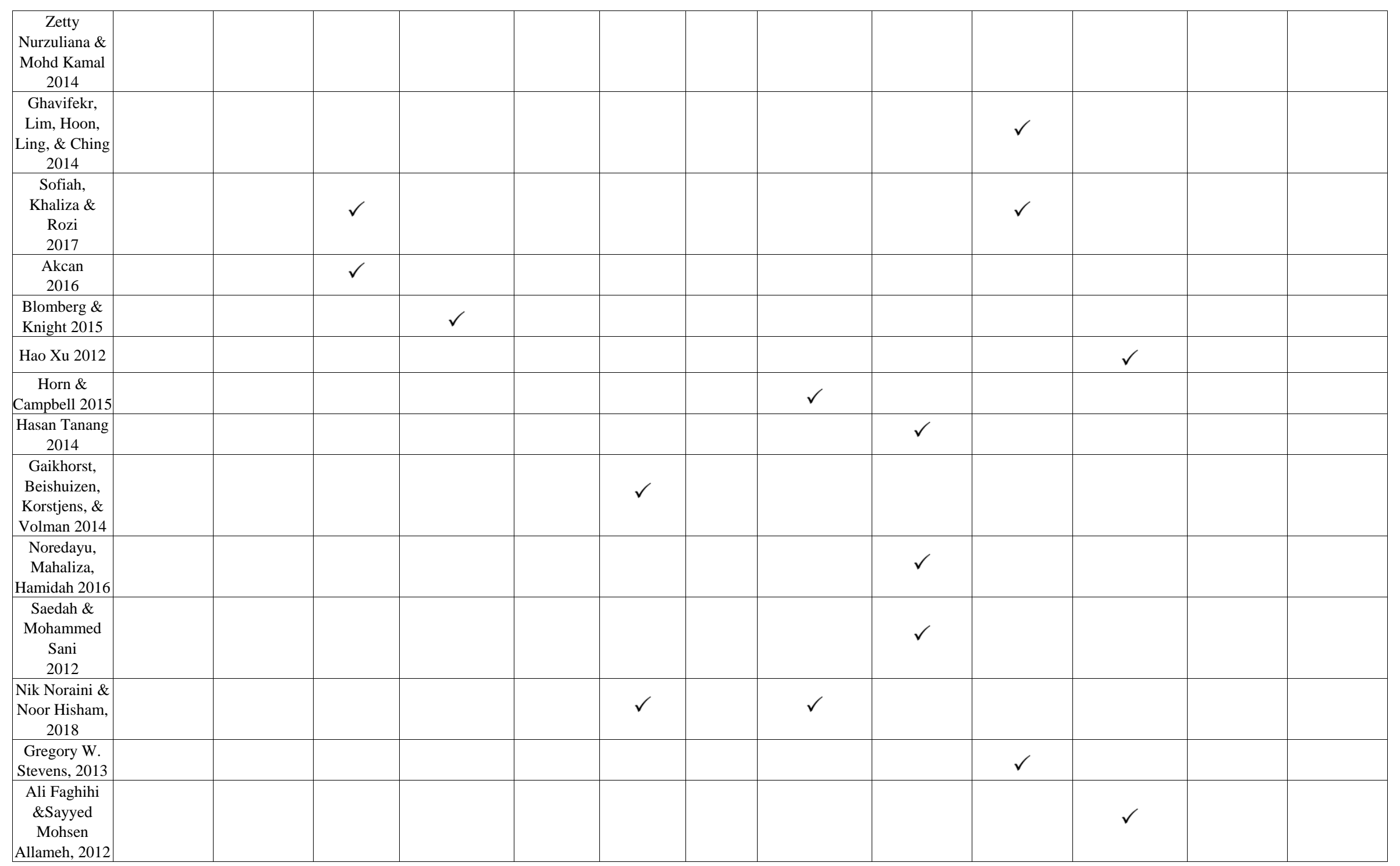




\begin{tabular}{|c|c|c|c|c|c|c|c|c|c|c|c|c|c|}
\hline \begin{tabular}{|c|} 
Inandi \& Gilic, \\
2016 \\
\end{tabular} & & & & $\checkmark$ & & & & & & $\checkmark$ & & & \\
\hline \begin{tabular}{|c|} 
Habib Mat \& \\
Kamaruzaman, \\
2012
\end{tabular} & & & & & & & & & $\checkmark$ & & & & \\
\hline \begin{tabular}{|c|} 
Avis M. \\
Masuda, \\
Michele M. \\
Ebersole \& \\
Diane Barrett, \\
2013 \\
\end{tabular} & & & & & & & & & & $\checkmark$ & & & \\
\hline \begin{tabular}{|c|} 
Muhammad \\
Faizal, \\
2016 \\
\end{tabular} & & & & $\checkmark$ & & & & & & & & & $\checkmark$ \\
\hline \begin{tabular}{|c|} 
Prasad Babu, \\
2013 \\
\end{tabular} & & & & $\checkmark$ & & & & & & & & & \\
\hline \begin{tabular}{|c|} 
Rusliza \\
Yahaya, 2017 \\
\end{tabular} & & & & & & & $\checkmark$ & & & & & & \\
\hline \begin{tabular}{|c|} 
Tang Keow \\
Ngang, \\
2014 \\
\end{tabular} & & & & & & & & & & & & $\checkmark$ & \\
\hline \begin{tabular}{|c|} 
Tang Keow \\
Ngang, \\
2015 \\
\end{tabular} & & & & & & & & & & & & $\checkmark$ & \\
\hline TOTAL & 1 & 1 & 3 & 6 & 1 & 3 & 2 & 2 & 4 & 5 & 2 & 2 & 1 \\
\hline
\end{tabular}


Table 1 showed various types of challenges faced by school administrators and educators in integrate and implement New Teacher Development Program in schools. The result from the analysis showed that there are twelve challenges to integrate and implement the program; attitude, self-efficacy, motivation, commitment, teacher professionalisms, emotional stress, perception and perspective, competency, readiness, class management, communication and support structure.

Table 2 displayed the analysis on the dimensions or features associated with New Teacher Development Program in previous studies. The dimensions are achievement enhancement, responsibility, classroom management, emotional relationship and management, problem-solving skills, support and guidance, self-confidence, transparence communication, skills and knowledge, commitment and intention to change, transformation and intervention, collective work and teamwork and also ethics \& personal development.

\section{Results \& Discussion}

\subsection{Challenges Faced by School Administrators and Educators to Integrate and Implement New Teacher Development Program in Schools.}

The results will be discussed based on the challenges that were mentioned most frequently from the review. From Table 1, there were twelve challenges faced by the school administrators in the process of integrating New Teacher Development Program in schools; attitude, self-efficacy, motivation, commitment, teacher professionalisms, emotional stress, perception and perspective, competency, readiness, class management, communication and support structure. Findings from this review showed that the new teacher commitment, attitude and readiness are the main challenges to initiate, develop and integrate New Teacher Development Program in schools. A study conducted by [6] reported that new teachers are a distinctive group of learners that experience adverse work conditions that may result in their leaving the profession. New teachers are a distinct professional group that experiences their jobs differently, different instruments and methodologies may be needed to attain a better understanding of their experience and commitment to the profession. According to [7] even though facing with many challenges, new teachers may need to be even more effective and give commitment than their more experienced colleagues.

Researched by [8] showed that although have high impact on these new teachers, aspects related to work commitment, emotional intelligence and work stress amongst the new teachers are less researched on. In order to improve new teacher's work commitment in the teaching profession, work stress should be managed efficiently. It also will help to develop and maintain human capital amongst teachers and to undergo dynamic changes in the education.

The teacher's attitude could either be positive or negative.

The teacher is only a setter of the stage, a supplier of material and opportunities, a provider of an ideal environment, a creator of conditions under which natural development takes place. Attitude is a degree of positive or negative affect associated with some psychological object. It is also a latent variable rather than an immediately observable variable. Teachers are different in their attitude and also differ in their methods to supply the pupil's deficiencies. There may be a definite relationship between teachers' attitudes to home background and their attitude to what is termed as reading readiness. Frequent changes are likely to develop indifferent attitudes among teachers towards their profession [9].

According to [10] readiness for change is a concept approached at either organizational or an individual level in organizations in various areas. Their level of readiness for change will be high if the teachers feel that they have a voice in making decisions. When the relationship between teachers' level of readiness for change and the prevalent school culture at schools where they work is considered, there was found a positive and significant relationship between cognitive readiness and all dimensions of school culture, and also between intentional readiness and support, bureaucratic and task culture while there was a negative significant relationship between emotional readiness and achievement culture and bureaucratic culture.

\subsection{Dimensions or Features Associated with New Teacher Development Program}

Table 2 showed the analysis on the dimensions or features associated with New Teacher Development Program in previous studies. The dimensions are achievement enhancement, responsibility, classroom management, emotional relationship and management, problem-solving skills, support and guidance, self-confidence, transparence communication, skills and knowledge, commitment and intention to change, transformation and intervention, collective work and teamwork and also ethics \& personal development. Emotional relationship and emotional management were most frequently mentioned from previous studies by six authors out of twenty-nine.

Teachers' work is relating with emotional, social, and dynamic in character. Educators put on view their personality when teaching and it is considered to be a significant factor in influencing teachers' work. The sphere of personality can be divided into thought, will, and emotion[11].

A teacher social-emotional competence is considered essential for creating a healthy classroom environment. It is 
characterized by high-quality student-teacher relationships and positive classroom management. A study conducted by [12] suggest that teachers' ratings of their own social and emotional skill positively relate to how they manage stress and their levels of burnout. When a teacher develops a positive relationship with their mentor, they are motivated to try new techniques or to reveal implementation challenges. The mentor-teacher relationship is a source of social support that positively impacts teachers' emotional functioning.

\section{Conclusions}

From the result of the systematic literature review, it is significant to understand the challenges and obstacles in implementing and integrating New Teacher Development Program in schools especially for the teacher's professional development. There were many challenges faced by the administrators and educators comprising of new teacher attitude, self-efficacy, motivation, commitment, teacher professionalisms, emotional stress, perception and perspective, competency, readiness, class management, communication and support structure. Based on the discussion, new teacher commitment, attitude and readiness were found to be the most significant challenges in order to integrate the program in schools and emotional relationship and emotional management are the main dimensions or features associated with New Teacher Development Program.

Teachers play an important role in the educational system including the new teachers. They are the key persons to carry out the teaching and learning session and develop the young generation. A positive educational environment will enhance teachers' job satisfaction and commitment to work, contribute to the construction of a positive school culture and help administrators considerably on readiness for change in schools. Teacher education and induction need to provide the new teacher with skills that can be applied in classrooms. Developing and maintaining positive and constructive relationships with students, parents, and colleagues to maximize and ensure relevance in learning outcomes require skills of communication, teamwork, and conflict resolution that need to be developed by novices.

It is necessary to analyze the situation at school before any educational planning is done. Every change should not be viewed in a vacuum and separate from the reality of school life. Bureaucratic rules, coercive strategies and administrative pressures will be the main obstacles to effective policy implementation. This is because the new teachers are important individuals who are directly involved in the process of implementing an education policy, thus ignoring teacher's readiness, commitment, ignoring teachers' needs and underestimating teacher resentment are not a wise action [4].

\section{Acknowledgements}

The author would like to thank the anonymous reviewers for their constructive feedbacks and also like to thank Associate Prof. Dr Yusof Bin Boon for reviewing this manuscript.

\section{REFERENCES}

[1] "Panduan Pelaksanaan PPGB 2015."

[2] "Modul Program Pembangunan Guru Baharu- Edisi 32014 (1).pdf." .

[3] F. Senom, A. Razak Zakaria, and S. Sharatol Ahmad Shah, "Novice Teachers' Challenges and Survival: Where do Malaysian ESL Teachers Stand?," Am. J. Educ. Res., vol. 1, no. 4, pp. 119-125, 2013.

[4] Habib Mat Som and Syed Kamaruzaman Syed Ali, "Komitmen Guru Dalam Pelaksanaan Kurikulum Dan Inovasi Berkesan," Masal. Pendidik., pp. 99-119, 2011.

[5] I. S. Horn and S. S. Campbell, "Developing pedagogical judgment in novice teachers: mediated field experience as a pedagogy for teacher education," Pedagog. An Int. J., vol. 10:2, pp. 149-176, 2015.

[6] H. A. Michel, "The First Five Years: Novice Teacher Beliefs , Experiences , and Commitment to the Profession," University of California, San Diego, 2013.

[7] G. J. Mavroulis, "The impact of mentor conversation on the classroom performance of novice teachers.Dissertation abstracts. International Section A: Humanities and Social Sciences.," 2013.

[8] Zakaria Mohd Arif, "Pengaruh Kecerdasan Emosi Terhadap Stres dan Komitmen Guru Novis," Tesis Doktor Falsafah. Universiti Utara Malaysia., 2015.

[9] Dr. B. Prasad Babu, "Attitude of student teachers towards their profession," Int. J. Soc. ..., vol. 2, no. 1, pp. 1-6, 2013.

[10] Y. Inandi and F. Giliç, “Relationship of Teachers' Readiness for Change with Their Participation in Decision Making and School Culture.," Educ. Res. Rev., vol. 11, no. 8, pp. 823833, 2016.

[11] S. Blomberg and B. A. Knight, "Investigating novice teacher experiences of the teaching dynamics operating in selected school communities in Finland," Improv. Sch., vol. 18, no. 2, pp. 157-170, 2015.

[12] Celene E. Domitrovich, "How Do School-Based Prevention Programs Impact Teachers? Findings from a Randomized Trial of an Integrated Classroom Management and Social-Emotional Program," Prev. Sci., vol. 17, no. 3, pp. 325-337, 2016. 